\title{
ASSESSMENT OF THE QUALITY OF MINERAL WATER, POKLEK AND VERBOC SPRINGS, IN THE AREA OF GLLOGOC, THROUGH PHYSICO-CHEMICAL ANALYSIS
}

\author{
Skender Sallahi ${ }^{1}$, Blerta Halimi ${ }^{2}$, Kreshnik Nuredini ${ }^{2}$, Betim Ismajli², \\ Bahrije Dobra $^{2 *}$, Skender Demaku ${ }^{2 *}$ \\ ${ }^{1}$ Ministry of Economic Development, Mining Department, Republic of Kosovo; \\ ${ }^{2 *}$ University of Pristine, Department of Chemistry, Faculty of Mathematical and Natural Sciences, \\ Pristina, Kosovo;
}

*Corresponding Authors Bahrije Dobra, Skender Demaku, e-mail: buki-d@ hotmail.com; skender.demaku@hotmail.com

Received April 2021; Accepted May 2021; Published June 2021;

DOI: https://doi.org/10.31407/ijees11.317

\begin{abstract}
The purpose of this paper was to monitor the quality of mineral water in the springs: Poklek and Verboc, in the area of Gllogoc, through analysis: physic-chemical and heavy metals. Water quality monitoring is mandatory, especially if it's used as drinking water, therefore mineral springs (Poklek-Verboc), contain various minerals, such as salts and sulfur composition. Further research is planned to be conducted for the physico-chemical characterization, which will follow up on time to time the changes in the composition of the various components of this water. Today it is much more common for mineral water to be bottled and used for drinking. Water should be rich in minerals beneficial to the human body, where, among the minerals we mention: Magnesium that protects the heart, kidneys, muscular system, and helps digestion: Calcium as a constituent of bone and important for the dental system: Bicarbonates in significant amounts, aid digestion and are positive, for assimilating energy in the right form, etc. The analysis of the mineral water in this work involved the determination of several physico-chemical parameters (COD, BOD, conductivity, $\mathrm{pH}$ value, etc) and some heavy metals ( $\mathrm{Zn}, \mathrm{Cu}, \mathrm{Cd}, \mathrm{Pb}, \mathrm{Co}, \mathrm{Ni}, \mathrm{Al}, \mathrm{Cr}, \mathrm{Mn}, \mathrm{As}, \mathrm{Sc}, \mathrm{Sb}$, $\mathrm{Hg}, \mathrm{Fe}$ and $\mathrm{Ag}$ ).
\end{abstract}

Keywords: Poklek-Verboc, mineral water; heavy metals, physical-chemical parameters. 